\title{
A METHOD OF ASSAYING ADRENAL CORTICAL HORMONES BASED ON A DECREASE IN THE CIRCULATING LYMPHOCYTES OF HYPOPHYSECTOMIZED RATS (LYMPHOPENIA METHOD)
}

\author{
TAKESHI NAKAO AND KOGO HIRAGA \\ Depaytmen! of Pharmacology, the Tokyo Jikei-Kai School of Medicine, Tokyo \\ Received for publication September 25, 1952
}

For the past ten years we have continued our researches in the biological assaying method of adrenal cortical hormones and have been studying the survival growth test, muscle work test, cold test, liver glycogen deposition test, potassium poisoning test and water intoxication test.

Most of these are designed to measure the effectiveness of assayed materials by observing the compensation of a phase of the multifarious functional deficiencies, each having its own feature, but they have unable to constitute the complete indices covering the effectiveness of hormones, and there are liable to creep in many drawbacks in showing the sensitivity or in the assaying technique.

It is, therefore, highly desirable to realize the completion of a method of chemical estimation in place of the foregoing biological assaying method. For the present, however, we cannot definitely claim that corticoids or the so called "chemocorticoids", which makes the estimation chemically possible, is the so called "biocorticoids" which is biologically active.

What is keenly desirable today above anything else is the accomplishment of a biological assaying method, which is at once accurate, sensitive and rapid, in order to satiate the demand following the remarkable development in the application of adrenal cortical hormones or for the accomplishment of the method of chemical estimation.

In order to meet the expectations in this connection we studied extensively, and we turned our attention to the circulating lymphopenia method of 11-oxycorticoid hormone having been announced by Dougherty and White(1) in 1943 and established an assaying method aimed at the decrease of circulating lymphocyte cells of hypophysectomized rats [O-kawara, 1950 (2)].

This method is not one which measures the effectiveness through a phase of compensation of adrenal cortical functional deficiency but is one which makes the extent of decrease of circulating lymphocytes as the indices of effectiveness. This method is yet to be perfected but it is altogether specific, accurate and sensitive, its technique is easily acquirable, the hypophysectomized rats can be used a number of times and that the assay results can be found 
out in a short time.

Having been able to secure cortisone acetate, the authors studied the results which had so fax been obtained by adrenal cortical extracts additional improvements having been effected in the meantime.

\section{MATERITAL AND METHOD}

Wistar rats, body weight $140-180 \mathrm{gm}$, were used for the test. Dict $\mathrm{A}$ of this department was given as feed and kept them in a uniform temperatured cote maintaining a uniform temperature at $24^{\circ} \mathrm{C}$. They were made to fast four hours prior to test.

Blood sample was obtained in the following procedure: rat fixed in dorsal position, shaved the hair of the lower leg and after skin section, exposed $v$. tibialis anterior, and by puncturing lightly obtained the free flowing blood the free flowing blood stops immediately by giving pressure with a piece of cotton).

Obtained the blood up to the point of 0.5 of a melangeur for leucocyte, diluthd the same with $2 \%$ acetic acid 'Turk's solution, and by means of Burker's chamber computed the leucocytes count in $1 \mathrm{cmm}$ thereof. As for smearing specimen May-Giemsa double dyeing was effected, and upon counting 200-600 of leucocytes obtained the Fercentage in lymphocyte count and multiplying the same by the leucocyte count determined the count of lymphocyte cells. Rats are extremely high in lymphocyte cells and an error in the computation of lymphocyte cells is almost negligible.

Adrenalectomy is carried out in the state of ether anesthesia through the lumbar route by one step within five minutes, and hypophysectomy also in the state of ether anesthesia by parapharyngeal approach, and after operation they were kept at a temperature of $24^{\circ} \mathrm{C}$, and gave water thereto.

Cortisone acetate was used in a solution of $0.3 \%$ benzyl alcohol plus $10 \%$ alcohol ; as for Merck's "Cortone Acetate" suspension, locally available, it was put in a $50 \%$ alcohol so that $500 \mu \mathrm{g}$ may be contained in $1 \mathrm{cc}$ and upon its use it was diluted and used in a $10 \%$ alcohol solution.

Regarding the adrenal cortical extract, it was used in $10 \%$ alcohol pius $0.9 \% \mathrm{NaCl}$ solution; as for other testing materials, they were used in a $10 \%$ alcohol solution or emulsion and given immediately after heating them to $38^{\circ} \mathrm{C}$.

The dose given was less than $1 \mathrm{cc}$ and has been injected hypodermically at the abdomen.

\section{PROCEDURES AND RESULTS}

1) In the case of a normal rat the fixing, blood obtaining procedure etc., prove as a stress and result in an unspecific decrease of the circulating lymphocyte count but it is known that by blocking the pituitary-adrenal system, or due 
to either hypophysectomy or adrenalectomy no decrease in the circulating lymphocyte count is caused by the stress.

Using hypophysectomized rats, we obtained the blood and observed the effect that alcohol, benzyl alcohol and adrenaline, and further the 11-desoxycorticosterone acetate that represents the action of mineralocorticoids and dehydroiso-androsterone, progesterone as well as cholesterol that approximate in their structure to the 11-oxycorticosteroid, cause in the count of the circulating lymphocyte count through the changes shown two hours after the administration of the testing materials.

The results were as shown in Table 1, none showing any significant change whatever. In the case of large doses of $100 \mu \mathrm{g}$ and $500 \mu \mathrm{g}$ of 11-desoxycorticosterone acetate, in particular, the changes were $-0.45 \%$ and $+3.1 \%$ respectively, and there was witnessed no decrease in the lymphopenic activity.

TABLE 1. Lymphopenic activity of various materials injected into hypophysectomized rats

\begin{tabular}{|c|c|c|c|c|c|c|c|}
\hline \multirow{2}{*}{ Material } & \multirow{2}{*}{ Dose } & \multirow{2}{*}{$\begin{array}{l}\text { No. } \\
\text { of } \\
\text { rats }\end{array}$} & \multicolumn{3}{|c|}{ Percent change in lymphocytes* } & \multirow{2}{*}{ S.D. } & \multirow{2}{*}{ S.E. } \\
\hline & & & Mean & $\begin{array}{l}\text { Maximum } \\
\text { response }\end{array}$ & $\begin{array}{l}\text { Minimum } \\
\text { response }\end{array}$ & & \\
\hline Handling & - & 5 & -2.6 & -18.6 & +11.5 & 11.2 & 5.0 \\
\hline $10 \%$ Alcohol & $1.0 \mathrm{cc}$ & 3 & +0.2 & -1.7 & +4.0 & 32 & 1.9 \\
\hline $\begin{array}{l}1.5 \% \text { Benzylaicohol } \\
+10 \% \text { Alcohol }\end{array}$ & $1.0 \mathrm{cc}$ & 3 & +1.0 & -3.7 & +7.9 & 6.1 & 3.5 \\
\hline Adrenaline & $\begin{array}{l}0.1 \mathrm{mg} \\
(1.0 c \mathrm{c})\end{array}$ & 4 & +6.6 & -10.9 & +23.2 & 14.7 & 7.4 \\
\hline $\mathrm{DOCA}$ & $\begin{array}{c}100 \mu \mathrm{g} \\
(1.0 \mathrm{ce})\end{array}$ & 4 & -0.5 & -16.3 & +17.9 & 14.1 & 7.1 \\
\hline DOCA & $\begin{array}{l}500 \mu \mathrm{g} \\
(1.0 \mathrm{co})\end{array}$ & 4 & +3.1 & -3.3 & +11.7 & 3.9 & 1.9 \\
\hline $\begin{array}{l}\text { Dehy dro-iso- } \\
\text { androsterone }\end{array}$ & $\begin{array}{c}150 \mu \mathrm{g} \\
(0.5 \mathrm{co})\end{array}$ & 4 & +7.8 & -2.1 & +11.8 & 10.4 & 5.2 \\
\hline Progesterone & $\begin{array}{c}200 \mu \mathrm{g} \\
(1.0 \mathrm{cc})\end{array}$ & 3 & -22 & -10.9 & +10.0 & 13.1 & 6.5 \\
\hline Cholesterol & $\begin{array}{c}200 \mu \mathrm{g} \\
(1.0 \mathrm{cc})\end{array}$ & 3 & +9.4 & $\dashv 4.0$ & +15.8 & 4.3 & 2.5 \\
\hline
\end{tabular}

*: Docrease in circulating lymphocytes 2 hours after giving the materials

$+:$ Increase,

- : Decrease

2) Cortisone acetate is hard to be dissolved in water but dissolves comparatively easily in alcohol-water. We used $10 \%$ alcohol solution and gave $20 \mu \mathrm{g}$ thereof to hypophysectomized rats and observed the change in the count of the circulating lymphocytes after two hours.

The results indicated that the variation in the response of rats were extremely great, the mean response only showing a decrease of $2.2 \%$.

Next, Merck's Cortone Acetate suspension was given in $10 \%$ alcohol solution. 
also $20 \mu \mathrm{g}$ thereof, and it resulted in a conspicuous decrease of $30.8 \%$.

Further, Cortone Acetate was washed six times in water and the crystals obtained this way were given in $10 \%$ alcohol solution, also $20 \mu \mathrm{g}$ thereof in the same way, and this showed an increase of $13.3 \%$ on the contrary. Thereupon we added benzyl alcohol, contained in Cortone Acetate suspension as preserver, to cortisone acetate at the rate of $0.3 \%$ and this in $10 \%$ alcohol solution and also $20 \mu \mathrm{g}$ thereof was given, and the result indicated a remarkable decrease of $33.1 \%$

That there is no lymphopenic activity in benzyl alcohol is as stated above. While the cause thereof is yet undetermined, we have decided since then to use cortisone acetate with $0.3 \%$ benzyl alcohol as stabilizer and in $10 \%$ alcohol solution. The results were as shown summarized in Table 2.

TABLE 2. Stabilization of cortisone acetate by benzyl alcohol

\begin{tabular}{|c|c|c|c|c|c|c|c|c|}
\hline \multirow{2}{*}{ Material } & \multirow{2}{*}{$\begin{array}{l}\text { Dose } \\
(\mu g)\end{array}$} & \multirow{2}{*}{$\begin{array}{l}\text { No. } \\
\text { of } \\
\text { rats }\end{array}$} & \multicolumn{3}{|c|}{ Percent decrease in lymphocytes* } & \multirow{2}{*}{ S.D. } & \multirow{2}{*}{ S.E. } & \multirow{2}{*}{$\begin{array}{c}\text { Significance } \\
\text { of } \\
\text { difference } \\
t(p=0.05)\end{array}$} \\
\hline & & & Mean & $\begin{array}{l}\text { Maximum } \\
\text { response }\end{array}$ & $\begin{array}{l}\text { Minimum } \\
\text { response }\end{array}$ & & & \\
\hline $\begin{array}{l}\text { Cortisone acetate } \\
10 \% \text { Alcohol sol. }\end{array}$ & 20 & 13 & 2.2 & 31.7 & -32.3 & 19.1 & 5.3 & $0.415^{* *}$ \\
\hline $\begin{array}{l}\text { Cortisone acetate } \\
\text { (suspension) } \\
10 \% \text { Alcohol sol. }\end{array}$ & 20 & 3 & 30.8 & 35.7 & 24.8 & 5.5 & 3.2 & $9.623^{* * *}$ \\
\hline $\begin{array}{l}\text { Cortisone acetate } \\
\text { (Crystal) } \\
10 \% \text { Alcohol sol. }\end{array}$ & 20 & 3 & -13.3 & -11.4 & -15.1 & 1.9 & 1.1 & $12.091 * * *$ \\
\hline $\begin{array}{l}\text { Cortisone acetate } \\
0.3 \% \text { Benzyl alcohol } \\
+10 \% \text { Alcohol sol. }\end{array}$ & 20 & 9 & 83.1 & 44.9 & 23.4 & 8.8 & 2.9 & $11.414^{* * *}$ \\
\hline
\end{tabular}

* : Decrease in circulating lymphocytes 2 hours after giving the materials

$\rightarrow$ : Increase

**: No significant change

***: Significant change

3) In order to see the variation in the lymphopenic activity between hypophysectomized rats and adrenalectomized rats after giving a hormone we used hypophysectomized rats, which are 10 days after the exstirpation, and adrenalectomized rats, four days after the extirpation, and two hours after giving $60 \mu \mathrm{g}$ of cortisone acetate compared the respective decreases. The results were as shown in Table 3 .

While hypophysectomized rats showed a remarkable decrease of $44.8 \%$, adrenalectomized rats indicated only a $16.8 \%$ decrease, and there was seen a remarkable variation in the decrease between the two. We have consequently decided to use hypophysectomized rats in observing the decrease in the circulating lymphocyte count due to 11-oxycorticosteroid hormone. 
TABLE 3. Dacrease in circulating lymphocytes showing variations between hypophysectomized rats and adrenalectomized rats by the use of cortisone acetate

\begin{tabular}{|c|c|c|c|c|c|c|c|c|}
\hline & \multirow{2}{*}{$\begin{array}{l}\text { No. } \\
\text { of } \\
\text { rats }\end{array}$} & \multicolumn{3}{|c|}{ Percent decrease in lym phocytes* } & \multirow{2}{*}{ S.D. } & \multirow{2}{*}{ S.E. } & \multirow{2}{*}{$\begin{array}{c}\text { Homogenity } \\
\begin{array}{c}\mathrm{F}_{0} \\
(\mathrm{p}=0.05)\end{array}\end{array}$} & \multirow{2}{*}{$\begin{array}{c}\text { Significance } \\
\text { of } \\
\text { difference } \\
t(\mathrm{p}=0.05)\end{array}$} \\
\hline & & Mean & $\begin{array}{r}\text { Maximum } \\
\text { response }\end{array}$ & $\begin{array}{l}\text { Minimum } \\
\text { response }\end{array}$ & & & & \\
\hline $\begin{array}{c}\text { Hypophysectomized } \\
\text { rats }\end{array}$ & 4 & 44.8 & 52 & 38 & 5.8 & \multirow[t]{2}{*}{2.9} & \multirow{2}{*}{1.937} & \multirow{2}{*}{$4.873^{* *}$} \\
\hline $\begin{array}{c}\text { Adrenalectomized } \\
\left.\text { rats }^{2}\right)\end{array}$ & 4 & 16.8 & 28 & 8 & 8.0 & & & \\
\hline
\end{tabular}

1) 10 days after hypophysectomy

2) 4 days after adrenalcctomy

*: Decrease in Iym phocytes 2 hours after $60 \mu \mathrm{g}$ cortisone acetate was given

**: Significant change

4) Variation by sex of hypophysectomized rats in lymphopenic activity due to 11-oxycorticosteroid hormone was observed by using male and female rats ten days after hypophysectomy was carried out and by comparing the decreases two hours after giving $15 \%$ g of cortisone acetate.

The results were as shown in Table 4, male rats indicating a decrease of $29 \%$ and females $32 \%$, but no significant change between the two was distinguishable.

TABLE 4. Decrease in circulating Iymphocytes of hypophysectomized rats (10 days after operation) on giving cortisone acetate, varjations by sex

\begin{tabular}{|c|c|c|c|c|c|c|c|c|}
\hline & \multirow{2}{*}{$\begin{array}{l}\text { No. } \\
\text { of } \\
\text { rats }\end{array}$} & \multicolumn{3}{|c|}{ Percent decrease in lymphocytes* } & \multirow{2}{*}{ S.D. } & \multirow{2}{*}{ S.E. } & \multirow{2}{*}{$\begin{array}{c}\text { Homogenity } \\
F_{0} \\
(p=0.05)\end{array}$} & \multirow{2}{*}{$\begin{array}{c}\text { Signilicance } \\
\text { of } \\
\text { difference } \\
t(p=0.05)\end{array}$} \\
\hline & & Mean & $\begin{array}{c}\text { Maximum } \\
\text { response }\end{array}$ & $\begin{array}{l}\text { Minimum } \\
\text { response }\end{array}$ & & & & \\
\hline Male & 5 & 29 & 38 & 24 & 6.67 & 2.98 & \multirow{2}{*}{1.124} & \multirow{2}{*}{$0.617^{* *}$} \\
\hline Female & 5 & 32 & 42 & 23 & 7.07 & $\$ .16$ & & \\
\hline
\end{tabular}

*: Dacrease in lymphocytes 2 hours after giving $15 \mu \mathrm{g}$ of cortisone acetate

** No signilicant change

5) Upon giving 11-oxycorticosteroid hormone to hypophysectomized rats, the relation between the lapse of time and decrease in circulating lymphocyte count was compared with the decreases on giving cortisone acetate $15 \mu \mathrm{g}$ and $60 \mu \mathrm{g}$ respectively upon the lapse of one hour, two hours and three hours. The results were as shown in Table 5, indicating a rapid decrease upon the lapse of two hours, and irrespective of the volume of the dose, there was seen no significant change ir decrease between two hours and three hours when surveyed from the results of analysis of variance. 
TABLE 5. Relation between lapse of time and decrease in circulating lymphocytes after. giving cortisone acetate to hypophysectomized rats

\begin{tabular}{c|c|c|c}
\hline \multirow{2}{*}{$\begin{array}{c}\text { Dose } \\
(\mu g)\end{array}$} & 1 & Lapse & af time \\
\cline { 2 - 4 } & $16.4 \pm 5.7^{*}$ & 2 & 3 \\
\hline 15 & $21.0 \pm 4.3$ & $32.0 \pm 3.2$ & $29.6 \pm 3.7$ \\
60 & $46.6 \pm 2.0$ & $43.6 \pm 4.0$ \\
\hline
\end{tabular}

* : Percentage in decrease of lymphocytes and standard error $(p=0.05)$ of hypophysectomized rats (10 days after operation)

6) Hypophysectomized rats can live 2-3 months after the operation; during this interval we tried to determine if there is any variation in the decrease of circulating lymphocyte count by giving 11-oxycorticosteroid hormone, using the same hypophysectomized rats and by giving $40 \mu \mathrm{g}$ of cortisone acetate on the 7 th day, 35th day, and 56th day respectively after the operation and compared the lymphopenia upon the lapse of two hours on each occasion. The results were as shown in Table 6 , indicating decreases of $41.4 \%, 39.1 \%$ and $41.1 \%$ respectively, and we could determine that there is no significant variation in lymphopenia among the three upon carrying out the analysis of variance.

TABLE 6. Relation between lapse of time after hypophysectomy and decrease in circulationg lymphocytes upon giving cortisone acetate

\begin{tabular}{c|c|c|c|c|c|c|c}
\hline $\begin{array}{l}\text { Lapsed days } \\
\text { after hypox. }\end{array}$ & $\begin{array}{c}\text { No. } \\
\text { of } \\
\text { rats }\end{array}$ & $\begin{array}{l}\text { Percent decrease in Iymphocytes* } \\
\text { Mean }\end{array}$ & $\begin{array}{c}\text { Maximum } \\
\text { response }\end{array}$ & $\begin{array}{c}\text { Minimum } \\
\text { response }\end{array}$ & S.D. & S.E. \\
\hline 7 & 4 & 41.4 & 54.1 & 32.9 & 9.04 & 4.52 \\
35 & 4 & 39.1 & 44.0 & 32.6 & 4.77 & 2.39 \\
56 & 4 & 41.1 & 48.0 & 36.3 & 5.28 & 2.64 \\
\hline
\end{tabular}

* : Dacrease in circulating lymphocytes 2 hours after giving $40 \mu \mathrm{g}$ of cortisone acetate

7) In order to observe the variation in the decrease of circulating lymphocyte count when 11-oxycorticosteroid hormone is given to hypophysectomized rats repeatedly at short intervals, $20 \mu \mathrm{g}$ of cortisone acetate was given repeatedly at the interval of two days and four days respectively to rats which are more than seven days after hypophysectomy was effected, and compared the decreases two hours after the administration.

The results were as shown in Table 7 , the mean decreases were $32.8 \%$, and $33.3 \%$, and the analysis of variance did not show any variation among them. 
TABLE 7. Decrease in circulating Iymphocytes upon repeated administrations of cortisone acetate to hypophysectomized rats

\begin{tabular}{|c|c|c|c|c|c|c|}
\hline \multirow{2}{*}{$\begin{array}{l}\text { Interval } \\
\text { (day) }\end{array}$} & \multirow{2}{*}{$\begin{array}{l}\text { No. } \\
\text { of } \\
\text { rats }\end{array}$} & \multicolumn{3}{|c|}{ Percent decrease in lymphocytes* } & \multirow{2}{*}{ S.D. } & \multirow{2}{*}{ S.F. } \\
\hline & & Mean & $\begin{array}{l}\text { Maximum } \\
\text { response }\end{array}$ & $\begin{array}{l}\text { Minimum } \\
\text { response }\end{array}$ & & \\
\hline 0 & 3 & 32.8 & 41.2 & 28.4 & 7.25 & 4.19 \\
\hline 2 & 3 & 32.8 & 44.9 & 18.4 & 13.66 & 7.90 \\
\hline 4 & 3 & 33.3 & 40.4 & 23.9 & 8.34 & 4.82 \\
\hline
\end{tabular}

* Decrease in circulating lymphocytes 2 hours after giving $20 \mu \mathrm{g}$ of cortisone acetate

8) Because of the results of the foregoing tests, we then employed rats of $140-180 \mathrm{gm}$ of more than one week aiter hypophysectomy was effected, regardless of their sexes, and making the decrease in the circulating lymphocyte count two hours after giving cortisone acetate as response, we tried to determine the relation between the dose and the response. The results are summarized in Table 8 and 9. In winter at the room temperature $\left(15-17^{\circ} \mathrm{C}\right)$ a dose of from $10 \mu \mathrm{g}$ to $70 \mu \mathrm{g}$; when cortisone acetate solution is given in winter heating the same to $38^{\circ} \mathrm{C}$. or thereabout, from $3.75 \mu \mathrm{g}$. to $60 \mu \mathrm{g}$. In summer at a room temperature the respective graded responses indicated in exactly the same range as when cortisone acetate solution was heated in winter. Also the logdose-response curve in this range indicated a straight line as shown in Fig. 1. However, when a dose higher than the one that indicates the maximum response was given, a decrease in the response was witnessed conversely.

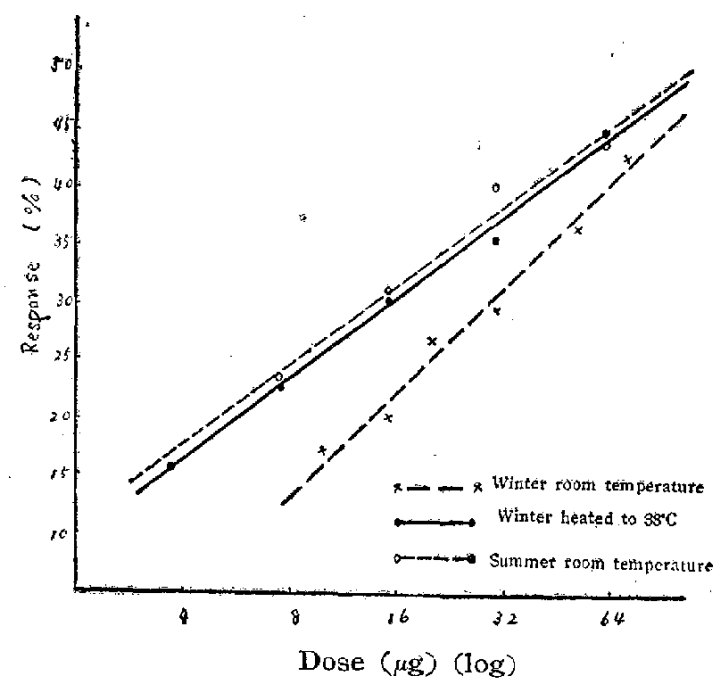

FIG. 1. Dose response curves of cortisone acetate by lym phopenia method. 
TABLE 8. Relation between the dose of cortisone acetate and the count in circulating Iym phocytes-hypophysectomized rats

\begin{tabular}{|c|c|c|c|c|c|c|c|c|}
\hline & & \multirow{2}{*}{$\begin{array}{l}\text { Dose } \\
(\mu \mathrm{g})\end{array}$} & \multirow{2}{*}{$\begin{array}{l}\text { No. } \\
\text { of } \\
\text { rats }\end{array}$} & \multicolumn{3}{|c|}{ Percent decrease in lymphocytes* } & \multirow{2}{*}{ S.D. } & \multirow{2}{*}{ S.E. } \\
\hline & & & & Mean & $\begin{array}{l}\text { Maximum } \\
\text { response }\end{array}$ & $\begin{array}{l}\text { Minimum } \\
\text { response }\end{array}$ & & \\
\hline \multirow{18}{*}{ 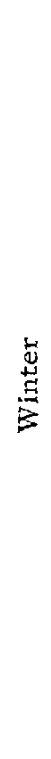 } & \multirow{10}{*}{ 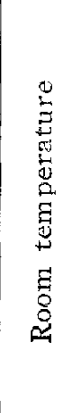 } & 10.0 & 9 & 17.4 & 33.6 & 5.2 & 12.66 & 4.22 \\
\hline & & 15.0 & 4 & 20.3 & 31.0 & 11.9 & 9.54 & 4.77 \\
\hline & & 20.0 & 8 & 20.7 & 55.9 & 8.3 & 14.50 & 5.12 \\
\hline & & 30.0 & 4 & 29.7 & 40.0 & 24.5 & 8.53 & 4.1.3 \\
\hline & & 60.0 & 8 & 36.7 & 48.8 & 22.1 & 10.37 & 3.66 \\
\hline & & 70.0 & 6 & 43.0 & 54.6 & 30.3 & 8.40 & 8.43 \\
\hline & & 100.0 & 11 & 38.0 & 59.9 & 19.9 & 12.26 & 3.69 \\
\hline & & 150.0 & 13 & 33.0 & 59.7 & 16.5 & 14.21 & 3.64 \\
\hline & & 200.0 & 4 & 33.8 & 35.6 & 32.0 & 5.97 & 2.99 \\
\hline & & 300.0 & 4 & 53.0 & 61.6 & 41.6 & 8.57 & 4.29 \\
\hline & \multirow{8}{*}{ 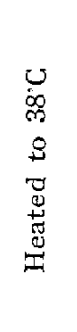 } & 1.9 & 10 & 7.0 & 35.1 & -31.2 & 19.84 & 6.27 \\
\hline & & 3.75 & 8 & 15.7 & 23.9 & 8.8 & 6.89 & 2.41 \\
\hline & & 7.5 & 10 & 22.6 & 39.3 & 14.5 & 8.42 & 2.66 \\
\hline & & 15,0 & 10 & 30.4 & 41.5 & 20.9 & 6.58 & 2.08 \\
\hline & & 30.0 & 8 & 85.9 & 52.2 & 24.1 & 10.69 & 3.78 \\
\hline & & 60.0 & 10 & 45.1 & 54.2 & 38.4 & 5.02 & 1.59 \\
\hline & & 120.0 & 14 & 38.8 & 63.5 & 7.9 & 15.14 & 4.05 \\
\hline & & 240.0 & 5 & 33.9 & 40.7 & 24.5 & 6.30 & 2.81 \\
\hline \multirow{4}{*}{ 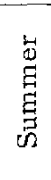 } & \multirow{4}{*}{ 总 } & 7.5 & 3 & 23.9 & 21.9 & 22.1 & 1.45 & 0.84 \\
\hline & & 15.0 & 3 & 31.3 & 33.3 & 23.1 & 4.85 & 2.80 \\
\hline & & 30.0 & 3 & 40.5 & 46.5 & 32.7 & 7.15 & 4.13 \\
\hline & & 60.0 & 3 & 44.2 & 46.4 & 41.5 & 2.31 & 1.33 \\
\hline
\end{tabular}

* Dacrease in circulating lymphocytes 2 hours after giving cortisone acetate

- : Increase

TADLE 9. Data on dose response curves of cortisone acetate by lymphopenia method

\begin{tabular}{|c|c|c|c|c|c|c|c|c|c|c|c|c|}
\hline \multirow{3}{*}{ 岕 } & \multirow[b]{2}{*}{$\begin{array}{c}\text { Room } \\
\text { temperature }\end{array}$} & \multirow{2}{*}{$\begin{array}{c}\begin{array}{c}\text { No. } \\
\text { of } \\
\text { points }\end{array} \\
6\end{array}$} & \multirow{2}{*}{$\begin{array}{c}\text { No. } \\
\text { of } \\
\text { rats }\end{array}$} & \multirow{2}{*}{$\begin{array}{c}\left.\begin{array}{c}\text { Correlation } \\
\text { coefficient } \\
\mathrm{T} \\
(\mathrm{p}=0.01\end{array}\right) \\
0.9974\end{array}$} & \multirow{2}{*}{$\frac{\begin{array}{c}\text { slope } \\
b\end{array}}{30.8}$} & \multirow{2}{*}{$\frac{\begin{array}{c}\text { standard } \\
\text { error } \\
\mathrm{Sb}\end{array}}{0.23}$} & \multirow{2}{*}{$\frac{\mid \begin{array}{c}\text { Fiducial } \\
\operatorname{limit} \\
(\mathrm{p}=0.05)\end{array}}{1.3}$} & \multirow{2}{*}{ 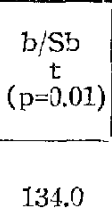 } & \multirow{2}{*}{\begin{tabular}{|}
$\begin{array}{c}\text { Regression } \\
\text { formula }\end{array}$ \\
$y=30.8 x-14.7$
\end{tabular}} & \multirow{2}{*}{\begin{tabular}{|c|}
$\begin{array}{c}\text { S.D. } \\
\text { about } \\
\text { the } \\
\text { line }\end{array}$ \\
0.84
\end{tabular}} & \multicolumn{2}{|c|}{$\begin{array}{c}\text { Homogenity } \\
\text { F } \\
(p=0.05)\end{array}$} \\
\hline & & & & & & & & & & & \multirow{2}{*}{25.15} & - \\
\hline & $\begin{array}{c}\text { Heated } \\
\text { to } \\
38 \mathrm{C}\end{array}$ & 5 & 46 & 0.9980 & 23.7 & 0.28 & 1.8 & 84.5 & $y=23.7 x+2.1$ & 0.79 & & 0.098 \\
\hline 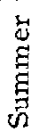 & $\begin{array}{c}\text { Room } \\
\text { temperature }\end{array}$ & 4 & 12 & 0.9904 & 23.0 & 0.56 & 4.8 & 47.1 & $y=23.0 x+4.2$ & 1.53 & - & \\
\hline
\end{tabular}


When the testing materials are given heated in winter or when the log-doseresponse line in summer is compared with the nonheated testing materials in winter, the inclination became less sharp and some significant changes in the grade was noticed. However, the two former cases evoked a decrease in circulating lymphocyte count by a very small dose of the testing materials by far smaller than the last.

9) By the same method as in test 8) and with cortisone acetate as standard, we assayed the potency of five kinds of adrenal cortical extract (ACE) in four doses, at the rate of three rats per dose.

The results mere as shown summarized in Tables 10 and 11 . The doseresponse curves of each of ACE were found parallel with the standard curves, and the fiducial limit was approximately around $\pm 15 \%$ with the exception of J-ACE No. 111 and S-No. 6.

TARLE 10. Assaying of potency of ACE by lymphopenia method (1) (Cortisone acetate used as standard)

\begin{tabular}{|c|c|c|c|c|c|c|}
\hline \multirow{2}{*}{$\frac{\mathrm{X}}{\text { (Vol. cc) }}$} & \multicolumn{6}{|c|}{$\mathbf{y}$} \\
\hline & Standard & J-No. $110^{*}$ & J-No. 111 & S-No. 6 & S-No. $7^{*}$ & T -Nọ. I \\
\hline $\begin{array}{l}1.30 \\
(0.2)\end{array}$ & 45 & 39 & 45 & 46 & 41 & 37 \\
\hline $\begin{array}{l}1.00 \\
(0.1)\end{array}$ & 30 & 32 & 35 & 39 & 33 & 32 \\
\hline $\begin{array}{c}0.70 \\
(0.05)\end{array}$ & 30 & 22 & 33 & 33 & 25 & 22 \\
\hline $\begin{array}{c}0.40 \\
(0.025)\end{array}$ & 23 & 17 & 21 & 23 & 19 & 16 \\
\hline & $\begin{array}{r}X=2+\log d \\
\text { J-No. } 1 \\
14 \text { dos } \\
\text { Standard }=0\end{array}$ & $\begin{array}{l}\text { se (cc) } \\
-X \text { shows } \\
\text { of vol. used } \\
\text { rtisone ace }\end{array}$ & $\begin{array}{l}=\text { Respons } \\
z \text { dose of } \\
\text { te } 300 \mu \mathrm{g}\end{array}$ & used a & S-No. 7-X & lows \\
\hline
\end{tabular}

10) Comparison was made between our testing method of assaying the potency of ACE with cortisone acetate as standard with "Liver Glycogen Deposition Test" [Veneing, Kazmin \& Bell, 1945 (3)] and "Cold Test" [Vogt, 1943 (4)].

The results were as shown in Table 12. There was seen no parallel relationship whatever among the potency of ACE having been computed by the three tests. Also the potency having been computed for each extract varied conspicuously by the test having been employed. 


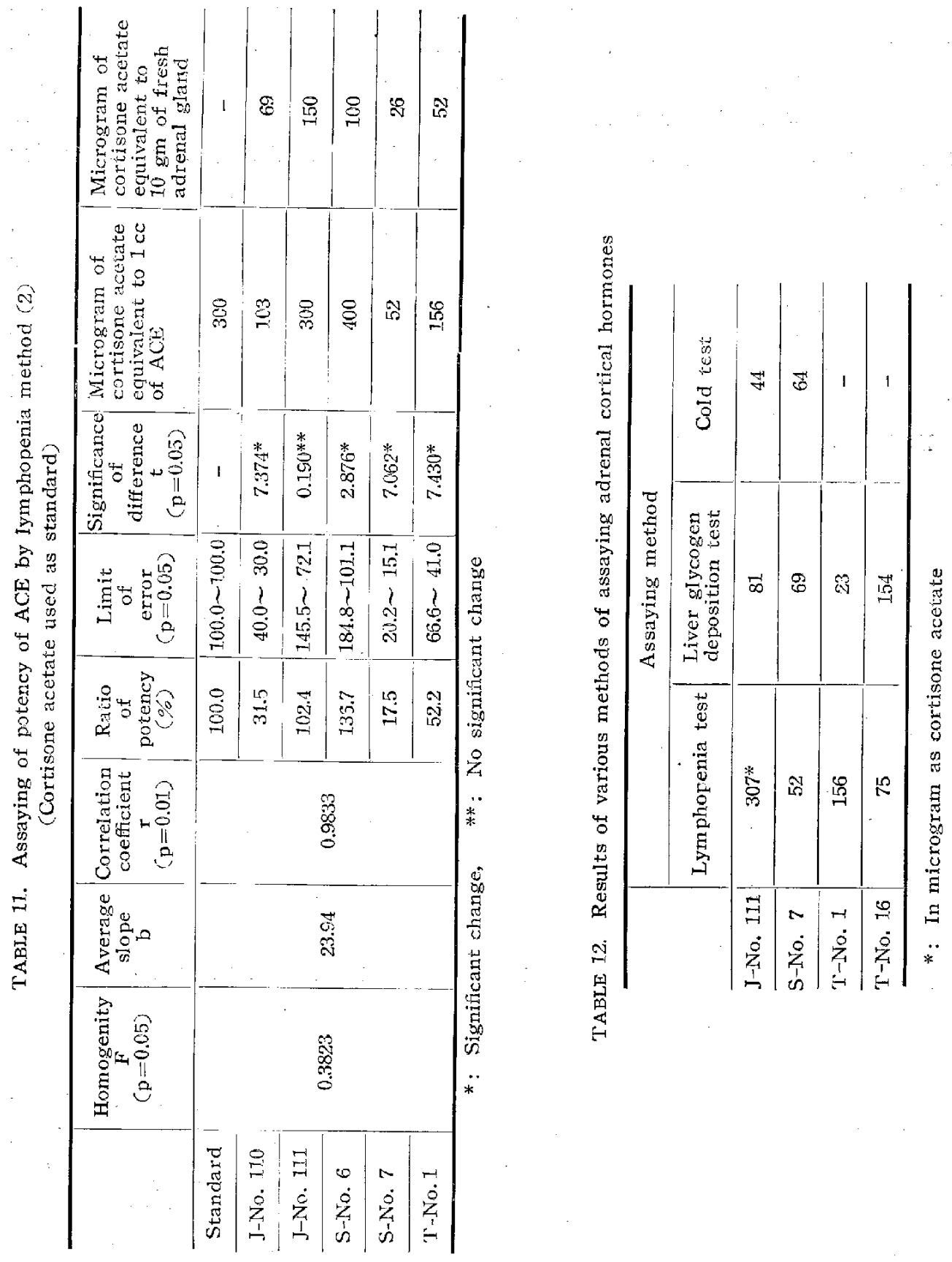

DISCUSSION

From the results of the above tests, we believe the method of making the lymphopenic activity in the circulating lymphocyte count of hypophysectomized rats, by 11-oxycorticosteroid hormone as the test target; can be used as the most accurate, sensitive and rapid testing method of adrenal cortical materials. 
This method brings about a distinct decrease in the lymphocyte count by 4 micrograms or higher of cortisone acetate. Its technique is simple as one week training is ample for one to get well trained, and the test result can be determined in a short period of time (10 hours).

The methods which have been used most as being accurate and sensitive: liver glycogen deposition test [Reinecke \& Kendall, 1942 (5); Eggleston, Johnston \& Dobriner, 1946 (6); Venning, Kazmin \& Bell, 1946 (3)] and cold test [Selye \& Schenker, 1938 (7)] are certainly accurate, but they require, comparatively speaking many animals and comparatively large quantities of the testing materials; particularly the former is complicated in its procedure involving many hours.

In the case of the latter, while the testing procedure is very simple; there are, as Vogt (1943) (4) pointed out, very strict restraints about the kind, strain, age, body-weight, etc., and as Dorfmann (1949) (8) said its use as a routine assay procedure accompanies great difficulties.

Regarding the method recently published by Speirs \& Meyer (1951) (9), with the eosinopenia in the circulating eosinophils of adrenalectomized mice as the testing target, is one which was established under entirely the same idea as our method. While it is generally recognized that eosinophils react on 11-oxycorticosteroid hormone more sensitively than lymplocytes, the exceptionally small number of eosnophils makes the errors in tests more liable. It also seems to make the variation of response related thereto much higher. Rats are exceptionally high in the count of lymphocytes, the rlatter occupying 70-80 percent of leucocytes. This minimzes the error in the count of lymphocytes, making the variation in response small likewise.

As for the causes of variations in the 1ymphopenia due to 11-oxycorticosteroid between hypophysectomized rats and adrenalectomized rats, we are inquiring into the data closely at present.

In the present method, we could not recognize the non-specific response due to the toxic material like benzyl alcohol seen in the method of Speirs \& Meyer. Consequently, it does not require any preceding treatment by adrenalin, etc.. Hypophysectomized rats live two-three months after the operation and they do not require the transplantation of DOCA pellets or any such treatment.

Our method, compared with that of Speirs \& Meyer, is less sharp in the slop of log-dose-response line and with cortisone acetate the range of straight line is between 4 micrograms and 60 micrograms, and while its sensitivity is inferior, we believe its accuracy is superior.

Incidentaly, our method is still on the way of its development; as a matter of fact through an impovement in the administration, of the testing materials we have bsen sucsessful in the elevation of sensitivity (still unpublished). 
As we are unable to secure various breeds of rats, it is much regretted that we cannot select any breed which is high in sensitivity.

Two hours after the adminisistration of hormone is most stabilized in the decrease of lymphocyte count, either large or small in dose, so the decreases seen two hours after the giving of testing materials have been set as the response of our method.

According to our research, we find decreases in the circulating lymphocytes by giving ACTH during the five days upon hypophysectomy was effected, and since this fact can be affirmed cytochemically, we decided to use hypophysectomized rats of more than seven days after the operation, which have lost their sensibility against ACTH.

Hypophysectonized rats live two-three months and do not indicate any conspicuous variation in their body weight for a considerable time, and even if they may be re-used during the period at three-four days intervals, there are no variations in sensibility, neither there is any variation in sensibility between males and females. All these facts serve our method exceptionally easy in its operation.

Sayers (1950) (10) says that the administration of large dosed adrenaline in case of hypophysectomized animals will see decreases in the circulating lymphocytes, but with the cxtent of adrenaline dose $\left(10^{-6}-10^{-}\right)$as contained in ACE, no decrease whatever is recognized.

In the case of non-adrenal steroids-progesterone, etc. of course, no decrease in the lymphocyte count can be seen even at a large dose of 11-desoxycorticosterone, and it only serves to show that the decrease in the circulating lymphocyte count is greatly specific.

As for the variation in the decrease of the lymphocytes due to seasonal atmospheric fluctuations, this can be removed by giving the testing materials heated to around $38^{\circ} \mathrm{C}$.

Like the instance of liver glycogen deposition test, the dose response curve of cortisone acetate and ACE in our method run parallel quite well.: Consequently it is possible to use cortisone acetate as the standard material.

In view of the above facts, in carrying on the assaying of the testing materials, there is no necessity of preparing the standard curve at the same time, it being done only on the testing materials, all that is required being to compare with the standard curve separately prepared beforehand to determine their effectiveness.

The assaying results show the errors, at 4 doses with 3 rats per dose, range generally around $\pm 15 \%$. We believe the assaying, at 4 doses with 4 rats per dose, insures the accuracy of the assaying results.

While the administration of a larger dose than what indicates the maximum 
responise entails a decrease in response conversely, this fact gives us much confusion in the assaying, and while again the cause is as yet undetermined, we believe this can be solved by giving doses in an extensive range below the maximum response.

The variation in the assaying results between our method and liver glycogen deposition test as well as cold test is due, as stated above, to the difference in the assaying target, and it is not due to any fault in the technique. In the case of assaying the potency strictly, we believe two or three testing methods should be employed concurrently.

Incidentally, we discovered that cortisone acetate solution can be stabilized by adding a slight dose of benzyl alcohol thereto, although its cause is still undetermined for the present.

\section{CONCLUSIONS AND SUMMARY}

In the above we have dealt with the assaying method of adrenal cortical hormones. Our method makes the decrease of the circulating lymphocytes of hypophysectomized rats two hours after the subcutaneous injection of 11-oxycorticosteroid hormone as the assaying target.

Hypophysectomized rats show a greater decrease in the circulating lymphocites due to 11-oxycorticosteroid hormone than adrenalectomized rats do.

No difference is seen between males and females of hypophysectomized rats in the decrease of the circulating lymphocyte cells due to the administration of 11-oxycorticosteroid hormone.

Minimal variation in the decrease of the circulating lymphocytes of hypophysectomized rats is seen two hours after the administration of 11-oxycorticosteroid hormone.

No variation is seen in the decrease after giving 11-oxycorticosteroid hormone even if hypophysectomized rats, more than seven days after the operation, be re-used at three-four days intervals.

Cortisone acetate can be stabilized by adding a slight dose of benzyl alcohol thereto.

Hypophysectomized rats do not show any decrease in the circulating lymphocyte cells through the administration of a non-specific agent.

Our assaying method is to be conducted as follows:

1) Conduct hypophysectomy of $140-80 \mathrm{gm}$ Wister rats, regardless of their sex.

2) Hypophysectomized rats, more than seven days after the operation, are made to fast.for four hoars, and tia testing material is to be heated to $39^{\circ} \mathrm{C}$, and injected subcutaneously.

3) Imnediately before the giving of the testing material and two hours 
after the giving, count the lymphocytes, and obtain the percentage in the decrease of the circulating lymphocytes.

4) Obtain the dose-responses and compute the potency by comparing with the standard.

By this method the log-dose-responses of cortisone acetate indicate a straight line between $3.75 \mu g-60 \mu \mathrm{g}$. Similar dose-responses are obtained by adrenal cortical extracts.

No lymphopenic effect is obtainable either by 11-desoxycorticosterone acetate or by non-adrenal steroids.

The assaying results of potency by this method do not concur with those obtained by either liver glycogen deposition test or cold test.

\section{REFERENCES}

1) Dougherty, T. F. ANd White, A.: Proc. Soc. Exper. Biol. \& Med. 53, 132 (1943)

2) O-KAWARA, H.: Folia pharmacol. japon. 46, 235 \& (1951)

9) Venning, E. H., Kazmin, V. E. ANo Beld, J. C.: Endocrinol. 33, 79 (1946)

4) VogT, M.: J. Physiol. 102, 341 (19.43)

5) REINICKE, K. M. AND KeNDALL, E. C.: Endocrinol. 31, 573 (1942)

6) EGgleston, N. M., Johnston, B. J. AND DORBINER, K.: Ibid. 33, 197 (1946)

7) SELYE, H. ANd ScHENKEL, V.: Proc. Soc. Exper. Biol. \& Med. 35, 518 (1938)

8) DorfMANN, R. I., Shipley, R.A., Ross, E., Schiller, S. AND HoRWITT, B.N.: Endocrinol. 38, 189 (1946)

9) SPEIRS, R. S. AND MEYER, R. K.: Ibid. 48, 316 (1951)

10) SAYERS, G.: Physiol. Rev. 39, 241 (1950) 